\title{
PKA Implicated in the Phosphorylation of Cx43 Induced by Stimulation with FSH in Rat Granulosa Cells
}

\author{
Keiichiro YOGO ${ }^{1)}$, Takuya OGAWA ${ }^{2)}$, Motofusa AKIYAMA ${ }^{1)}$, \\ Norihiro ISHIDA-KITAGAWA ${ }^{1)}$, Hiroshi SASADA ${ }^{3)}$, Eimei SATO $^{3)}$ and \\ Tatsuo TAKEYA ${ }^{1)}$
}

${ }^{1)}$ Graduate School of Biological Sciences, Nara Institute of Science and Technology, Ikoma, Nara 630-0101, Japan, ${ }^{2}$ Life Sciences Division, Lawrence Berkeley National Laboratory, 1 Cyclotron Rd, Mail Stop 84R0171, Berkeley, CA 94720-8268, USA and ${ }^{3)}$ Laboratory of Animal Reproduction, Graduate School of Agricultural Science, Tohoku University, 1-1 Tsutsumidori-amamiyamachi, Aoba-ku, Sendai 981-8555, Japan

\begin{abstract}
Connexin 43 (Cx43)-mediated gap junctional communication in granulosa cells is crucial for germ line development and postnatal folliculogenesis. We previously showed that folliclestimulating hormone (FSH) promoted phosphorylation of $\mathrm{Cx} 43$ in rat primary granulosa cells. We further identified Ser365, Ser368, Ser369, and Ser373 in the carboxy-terminal tail as the major sites of phosphorylation by FSH, and found that the phosphorylation of these residues was essential for channel activity. In this study, we investigated the protein kinase(s) responsible for FSH-induced phosphorylation. H89, a cyclic AMP-dependent protein kinase (PKA) inhibitor, inhibited FSHinduced phosphorylation both in vivo and in vitro, whereas PD98059, a mitogen-activated protein kinase kinase (MEK) inhibitor, had little effect on the phosphorylation level. $\mathrm{Ca}^{2+}$-dependent protein kinase (PKC) appeared to negatively regulate phosphorylation. Phosphopeptide mapping with or without H89 treatment indicated that PKA could be responsible for phosphorylation of the four serine residues. In addition, the purified catalytic subunit of PKA could phosphorylate the recombinant Cterminal region of $\mathrm{Cx} 43$, but not the variant in which all four serine residues were substituted with alanine. These results suggest that FSH positively regulates Cx43-mediated channel formation and activity through phosphorylation of specific sites by PKA.
\end{abstract}

Key words: Connexin 43, FSH, Gap junction, Granulosa cells, PKA

(J. Reprod. Dev. 52: 321-328, 2006)

G ap junctions are specialized plasma membrane associations containing intercellular channels that are formed by the association of two hemichannels (connexons), one provided by each of the communicating cells [1-3]. Each connexon is a hexamer subunit, or connexin, which is needed to form a central pore and is the product of members of a growing multigene family. At present, 20

Accepted for publication: January 13, 2006

Published online: February 13, 2006

Correspondence: K. Yogo (ke-yogo@bs.naist.jp) different genes have been identified in mammals that code for different members of the connexin family [4]. Their primary sequences in proteins are fairly conserved throughout the species, with four hydrophobic membrane spanning domains and two extracellular domains. In contrast, the carboxy-terminal tail region is unique in each connexin protein, and this diversity could be an indicator and/or cause of the potential structural and regulatory complexities of gap junction channels (GJC). Indeed, connexins are expressed in 
a variety of cells, and each cell type has its own characteristic pattern of expression of connexin genes reflecting their functional roles. In ovarian follicles, for example, intercellular communication between oocytes and somatic cell components is well recognized as crucial for both folliculogenesis and oogenesis [5, 6], and transfer of ions, metabolites, and second messenger molecules through GJC might play a principal role in the process $[7,8]$. We previously detected transcripts of five connexin (Cx) genes, including those for Cx43 and the newly identified Cx60, in porcine ovarian follicles $[9,10]$, and observed that folliclestimulating hormone (FSH) could induce $\mathrm{C} \times 43$ mRNA expression in rat ovarian follicles. Subsequent treatment with leutenizing hormone (LH) significantly reduced the Cx43 mRNA level [10], suggesting that Cx43 is a FSH-responsive gene product and also that it might play an important role in the physiological functions of FSH.

Cx43-mediated channel formation and activity have been reported to be regulated at multiple levels by phosphorylation, including the assembly of connexons in the plasma membrane, degradation of connexin, and direct effects on channel activities [11-15]. In fact, we found that FSH promoted phosphorylation of $\mathrm{C} \times 43$ in rat primary granulosa cells [16]. We further identified Ser365, Ser368, Ser369, and Ser373 in the carboxyterminal tail as major sites of phosphorylation on stimulation with FSH, and found that phosphorylation of these four residues was essential for channel activity [16]. However, it was not clear which kinase(s) phosphorylates the serine residues of $\mathrm{Cx} 43$. In the present study, we tried to identify the kinase(s) using a FSH-responsive rat primary granulosa cell culture system and in vitro phosphorylation assay. We found that cAMPdependent protein kinase (PKA) plays a major role under the influence of FSH.

\section{Materials and Methods}

\section{Preparation and culture of granulosa cells}

Twenty one-day-old female SD rats (Japan SLC, Shizuoka, Japan) were injected with $2 \mathrm{mg}$ of diethylstilbestrol (DES) in sesame oil once daily for 4 days, and ovaries were collected $48 \mathrm{~h}$ after last injection [17]. The ovaries were rinsed with Ham's F12-Dulbecco's modified Eagle's medium (F12/
DMEM) supplemented with $20 \mu \mathrm{g} / \mathrm{ml}$ gentamycin and $0.5 \mu \mathrm{g} / \mathrm{ml}$ fungizone, and dissected free of fat and connective tissues. Granulosa cells were released by puncturing follicles with 26-gauge needles in F12/DMEM medium and were incubated in $0.25 \%$ trypsin and $50 \mu \mathrm{g} / \mathrm{ml}$ DNaseI for $1 \mathrm{~min}$, followed by the addition of $50 \mu \mathrm{g} / \mathrm{ml}$ trypsin inhibitor. The cells were then washed three times with F12/DMEM and resuspended in culture medium (F12/DMEM, 0.1\% BSA, $5 \mu \mathrm{g} / \mathrm{ml}$ insulin, $5 \mu \mathrm{g} / \mathrm{ml}$ transferrin, $20 \mu \mathrm{g} / \mathrm{ml}$ gentamycin and 0.5 $\mu \mathrm{g} / \mathrm{ml}$ fungizone) supplemented with $5 \mu \mathrm{g} / \mathrm{ml}$ fibronectin. The cells were then plated in poly-Dlysine-coated dishes at a density of $5 \times 10^{5} / \mathrm{cm}^{2}$ and cultured for $20-24 \mathrm{~h}$ in an atmosphere of $5 \% \mathrm{CO}_{2} /$ $95 \%$ air at $37 \mathrm{C}$. When necessary, granulosa cells thus prepared were stimulated with FSH (100 ng/ $\mathrm{ml}$; Vitro Diagnostics Inc.) for $4 \mathrm{~h}$.

\section{Western blot analysis}

Cells were washed with phosphate-buffered saline (PBS) and lysed in lysis buffer-1 [50 mM Tris$\mathrm{HCl}$ (pH 7.4), $150 \mathrm{mM} \mathrm{NaCl}, 2 \mathrm{mM}$ EDTA, $2 \mathrm{mM}$ PMSF, $2 \mathrm{mM} \mathrm{Na}_{3} \mathrm{VO}_{4}, 20 \mathrm{mM} \mathrm{NaF}, 10 \mathrm{mM} \mathrm{N}-$ ethylmaleimide, $100 \mathrm{KIU} / \mathrm{ml}$ aprotinin and $1 \%$ Triton-X 100] for $10 \mathrm{~min}$ at $4 \mathrm{C}$. Cell lysates were collected in tubes and centrifuged. The supernatants were solubilized with $2 X$ sample buffer [125 mM Tris- $\mathrm{HCl}$ (pH 6.8), 4\% SDS, 20\% glycerol, $0.1 \mathrm{mg} / \mathrm{ml}$ bromophenol blue, and $10 \% 2-$ mercaptoethanol]. Proteins were separated by SDS-polyacrylamide gel electrophoresis (PAGE) and transferred to PVDF membranes (Millipore) by electrophoresis. The membranes were rinsed in PBS containing 5\% BSA and $0.1 \%$ Tween- 20 for $1 \mathrm{~h}$, and incubated with anti-Cx43 antibody (Sigma), anti-ERK antibody (Promega), or antiphosphorylated ERK antibody (Promega) for 1-2 $\mathrm{h}$ at room temperature followed by incubation with a secondary antibody (sheep anti-mouse IgG or Protein-A conjugated with horseradish peroxidase, Amersham Biosciences) in 2.5\% skim milk/PBS for $1 \mathrm{~h}$. After washing, signals were detected with an enhanced chemiluminescence (ECL) reagent (Amersham-Pharmacia-Biotech).

\section{In vitro phosphorylation reaction of recombinant Cx43-CT protein}

Rat 6x His-tagged Cx43-CT (E227-I382) or Cx43CTS4A (S365/368/369/373A) (Fig. 1) were expressed in E. coli. and purified as described 


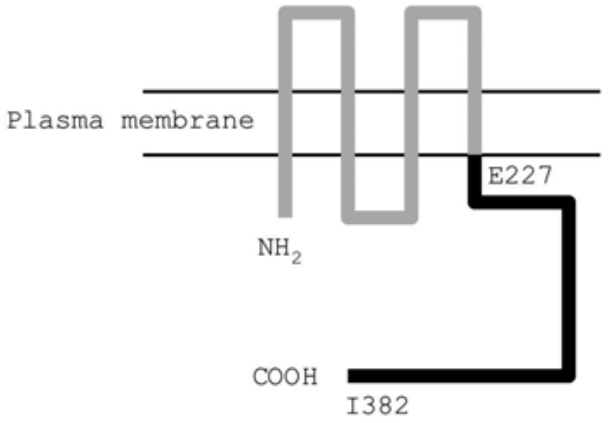

$6 \mathrm{xHis}-\mathrm{Cx} 43-\mathrm{CT}$

HHHHHHELFYVFFKGVKDRVKGRS DPYHATTGPLSPSKDCGSPKYAYF NGCSSPTAPLSPMSPPGYKLVTGD RNNSSCRNYNKQASEQNWANYSAE QNRMGQAGSTISNSHAQPFDFPDD NQNAKKVAAGHELQPLAIVDQRPS SRASSRASSRPRPDDLEI

Fig. 1. Construction and expression of a recombinant C-terminal domain of Cx43. A cDNA encoding the cytoplasmic tail of rat Cx43 (Cx43-CT: amino acid residues from E227 to I382) was subcloned into a 6x His-tagged expression vector, pQE31 (QIAGEN).

previously [16]. Cell lysates were prepared as follows. Granulosa cells were stimulated with FSH $(100 \mathrm{ng} / \mathrm{ml})$ for $4 \mathrm{~h}$, lysed with lysis buffer-2 (50 $\mathrm{mM}$ Hepes, $100 \mathrm{mM} \mathrm{NaCl}, 50 \mathrm{mM} \mathrm{NaF}, 1 \mathrm{mM}$ $\mathrm{Na}_{3} \mathrm{VO}_{4}, 1 \%$ Triton X-100, 2 mM PMSF, and 100 $\mathrm{KIU} / \mathrm{ml}$ aprotinin), and centrifuged at $17,000 \times \mathrm{g}$ for $5 \mathrm{~min}$. The supernatant fraction was stored at $80 \mathrm{C}$ prior to use. For in vitro protein kinase reactions, $2.5 \mu \mathrm{g}$ of Ni-NTA resin (Qiagen)-bound Cx43-CT was mixed with $6 \mu$ of 5X kinase buffer [100 mM Tris- $\mathrm{HCl}(\mathrm{pH} 7.5)$, and $25 \mathrm{mM} \mathrm{MgCl}_{2}$ ], 1.5 $\mu \mathrm{l}$ of $200 \mathrm{mM} \mathrm{MgCl}, 5 \mu \mathrm{l}$ of $\left[\gamma^{3}{ }^{32} \mathrm{P}\right]$ ATP $(111 \mathrm{TBq} /$ $\mathrm{mmol}$ ), and $1.5 \mu \mathrm{l}$ of $100 \mu \mathrm{M}$ ATP, and the volume was adjusted to $25 \mu \mathrm{l}$ with deionized water. When necessary, $50 \mu \mathrm{M}$ of H89 was included [18]. Five microliters of cell lysate or the catalytic subunit of PKA (Sigma) was added to the reaction mixture, which was then incubated for $30 \mathrm{~min}$ at $30 \mathrm{C}$. The resins were then washed and solubilized with sample buffer.

\section{Phosphopeptide mapping}

Two-dimensional phosphopeptide mapping and phosphoamino acid analysis were performed as described previously [19]. Briefly, labeled Cx43-CT was digested with TPCK-trypsin and the phosphopeptides were resolved on cellulose thinlayer chromatography (TLC) plates (Merck) by electrophoresis using $1 \%$ ammonium bicarbonate buffer, $\mathrm{pH} 8.9$, for $30 \mathrm{~min}$ at $1 \mathrm{kV}$ in the first dimension and ascending chromatography using phosphochromatography buffer (37.5\% n-butyl alcohol, $25 \%$ pyridine, $7.5 \%$ acetic acid, and 30\% deionized water) in the second dimension. The labeled peptide signals were detected by radioautography.
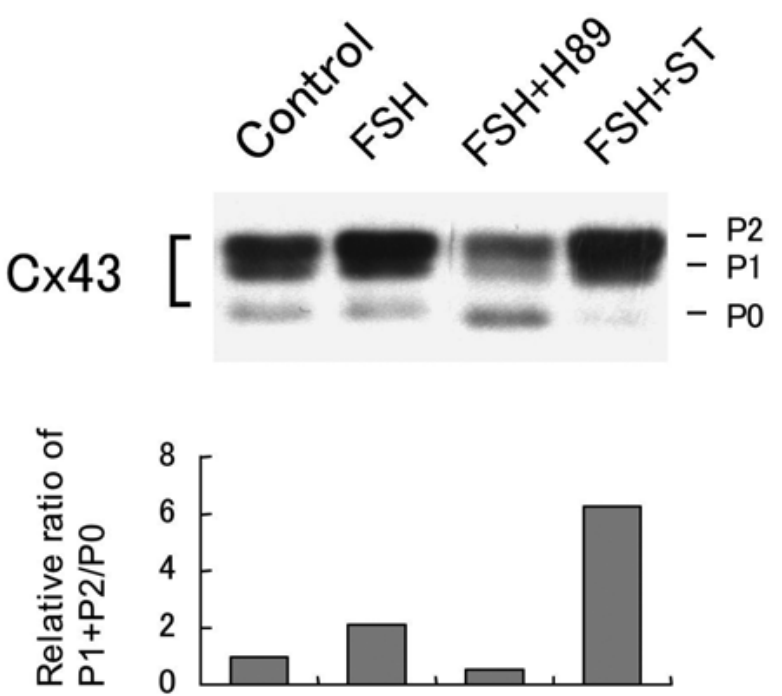

Fig. 2. Effects of $\mathrm{H} 89(50 \mu \mathrm{M})$ and staurosporin (ST) (50 ng/ $\mathrm{ml}$ ) on FSH-induced phosphorylation of Cx43. Rat primary granulosa cells were cultured with or without FSH for $4 \mathrm{~h}$ in the presence of the indicated inhibitor, H89 $(50 \mu \mathrm{M})$ or ST $(50 \mathrm{ng} / \mathrm{ml})$, and subjected to Western blot analysis (upper panel). P1 and P2 indicate the hyperphosphorylated forms, whereas P0 corresponds to the hypophosphorylated form of $\mathrm{Cx} 43$. Densitometric scanning of each form of Cx43 was conducted to quantify the ratio of the P1 + P2 forms to the P0 form. The ratio was normalized to control values (lower panel).

\section{Results}

PKA enhances while PKC suppresses phosphorylation of $C \times 43$

To identify the possible protein kinase involved in phosphorylation of $\mathrm{Cx} 43$ induced by stimulation with FSH in granulosa cells, we tested inhibitors for 

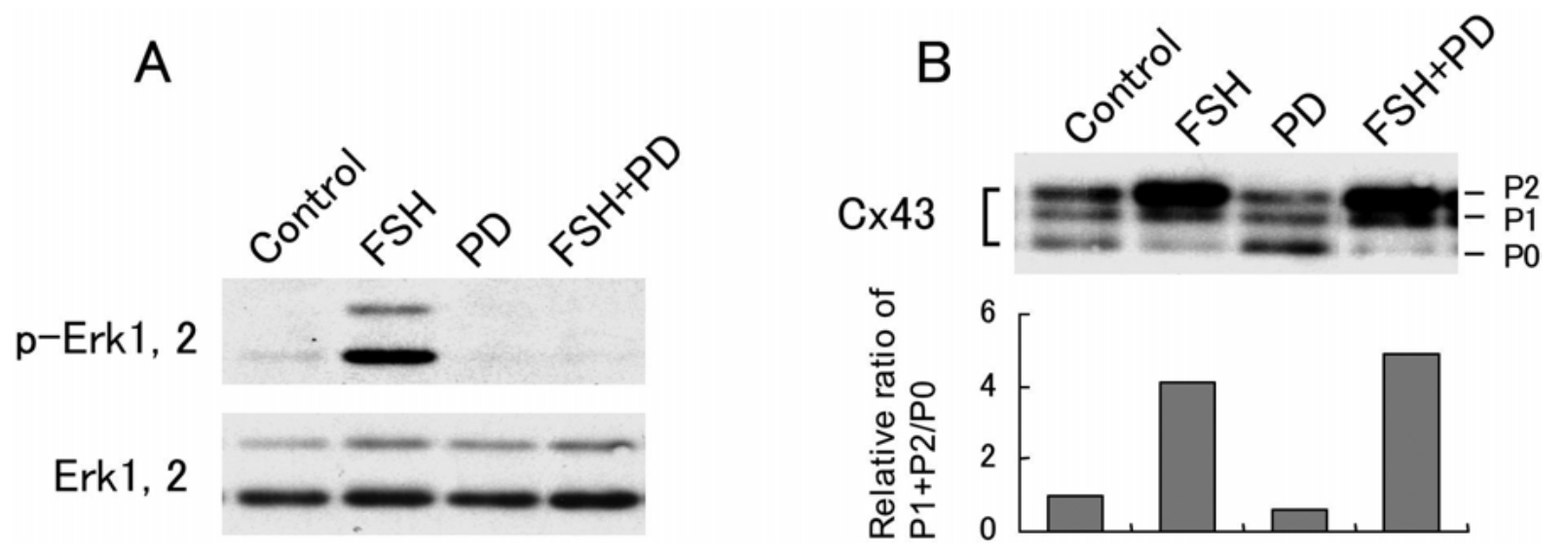

Fig. 3. Effect of a MEK inhibitor on Cx43 phosphorylation. (A) Granulosa cells were treated for 4 h with $50 \mu \mathrm{M}$ of PD98059 under conditions with or without FSH, and subjected to Western blot analysis with anti-ERK antibody or antiphosphorylated ERK antibody. (B) Granulosa cells were treated as in (A) and subjected to Western blot analysis with anti-Cx43 antibody (upper panel). The ratio of P1 + P2 to P0 was measured as in Fig. 1 (lower panel).

protein serine kinases that are known to be activated downstream of FSH signaling. As shown in Fig. 2, we confirmed that FSH increased hyperphosphorylation of Cx43 (P1 and P2) as previously reported; three bands (P0, P1, and P2) were observed by Western blotting throughout the incubation period, and a characteristic feature of the FSH-stimulated cells was a significant elevation in the levels of the P2 form after $4 \mathrm{~h}$. With regard to this, when immunoprecipitated $\mathrm{Cx} 43$ was treated with intestine phosphatase, the slowly migrating bands (P1 and P2) disappeared and consequently, the intensity of P0 increased, implying that the appearance of the slower bands was due to hyperphosphorylation (data not shown). When H89, a PKA inhibitor, was added to the culture medium in the presence of FSH, phosphorylation appeared to be significantly suppressed, indicating a major role for a PKA-dependent pathway (Fig. 2). Since the level seen after H89 treatment appeared to be lower than that in the control cells, PKA could also play a role in FSH-unstimulated cells. In contrast, staurosporin (ST), an inhibitor of $\mathrm{Ca}^{2+}$ dependent protein kinase (PKC), enhanced FSHinduced hyperphosphorylation. With regard to this, we found that 12-O-tetradecanoylphorbol-13acetate, a PKC activator, decreased the level of phosphorylated $\mathrm{Cx} 43$ in rat primary granulosa cells (data not shown), suggesting that the PKC pathway plays a negative role in phosphorylation of $\mathrm{Cx} 43$.

\section{ERK is dispensable in phosphorylation of C $x 43$}

The above results showed that a PKA-dependent pathway played a major role in phosphorylation of Cx43 induced by stimulation with FSH. In this regard, extracellular signal-regulated kinase (ERK) was reported to phosphorylate $\mathrm{Cx} 43$ in vivo and in vitro $[11,13,20]$, and FSH is also known to activate ERK in rat granulosa cells downstream from the PKA pathway [21]. We then tested the effect of PD98059, a mitogen-activated protein kinase kinase (MEK) inhibitor, on the level of phosphorylated Cx43 after FSH treatment. Although activation of ERK1/2 could be confirmed (Fig. 3A), PD98059 showed no effect on the level of phosphorylated Cx43 under the conditions used (Fig. 3B), suggesting that ERK activity was not essential for FSH-dependent phosphorylation of Cx43.

\section{Phosphorylation of Cx43 in vitro}

To further confirm the involvement of PKA in phosphorylation of Cx43, we carried out an in vitro phosphorylation reaction using a recombinant Cx43 carboxy-terminal domain (Cx43-CT). We previously found that recombinant $\mathrm{Cx} 43-\mathrm{CT}$ could be phosphorylated in vitro using rat granulosa cell lysate, and the sites of phosphorylation were identical to those observed in vivo [16]. We, therefore, expressed and purified 6x Histidinetagged Cx43-CT (Fig. 1) as reported previously, and examined whether H89 treatment affected phosphorylation in vitro. As shown in Fig. 4, the addition of $\mathrm{H} 89$ to the reaction mixtures 


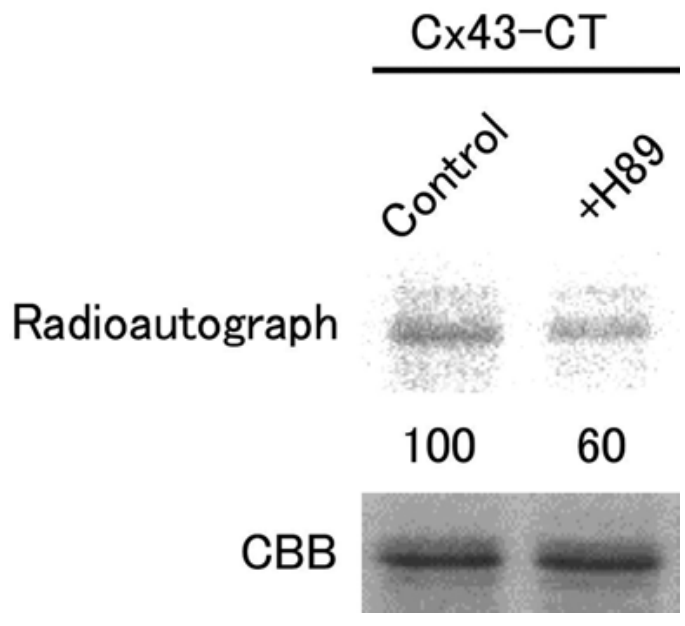

Fig. 4. Effect of H89 on Cx43-CT phosphorylation in vitro. The effects of $\mathrm{H} 89$ on phosphorylation reactions in vitro were examined using $\mathrm{C} \times 43-\mathrm{CT}$ as a substrate. The recombinant $\mathrm{Cx} 43-\mathrm{CT}$ was mixed with lysates from FSH-treated granulosa cells in the presence or absence of $50 \mu \mathrm{M}$ of H89. Reaction products were separated by SDS-PAGE and monitored by radioautography (upper panel). The gel was then stained with $\mathrm{CBB}$, and the amount of Cx43-CT was determined (lower panel). The radioactivity of each lane was normalized to the protein concentration. The relative values against lane 1 are shown under the upper panel.

significantly reduced the level of phosphorylated Cx43-CT. Tryptic peptide mapping of the thus labeled Cx43-CT showed no significant changes in the mapping profiles among the H89-treated and untreated conditions (Fig. 5), indicating that PKA had no selectivity among the four serine residues, but that it could be responsible for phosphorylation of all of the residues. To further confirm the involvement of PKA, we performed in vitro phosphorylation reactions using the purified catalytic subunit of PKA and either Cx43-CT or Cx43-CTS4A in which Ser365, Ser368, Ser369, and Ser373 residues were substituted with alanine (Fig. 6). As a result, the potential of $\mathrm{C} \times 43-\mathrm{CT}$ as a substrate could be observed, and no labeling was detected with Cx43-CTS4A, indicating that these four serine residues were actually target sites for PKA.

\section{Discussion}

We and others have reported that expression of

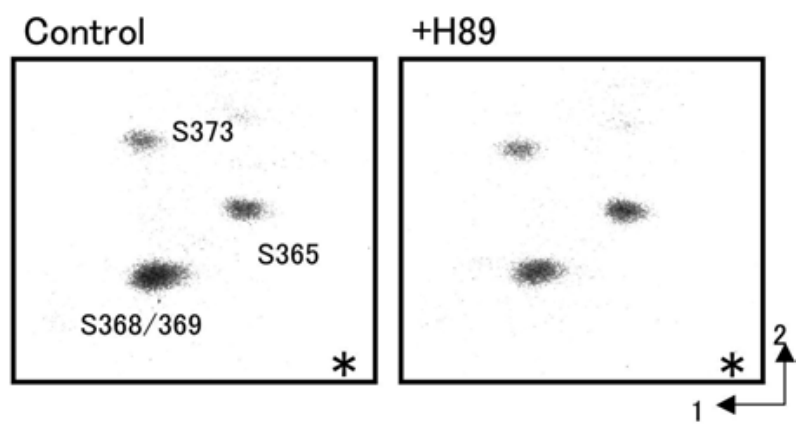

Fig. 5. Two-dimensional tryptic peptide mapping of Cx43CT phosphorylated in vitro. Recombinant Cx43-CT was phosphorylated as in Fig. 4, then digested with TPCK-trypsin. The resulting peptides were separated as described in "Materials and Methods". Three major phosphopeptide spots corresponded to S365, S368/369, and S373 [16]. The same amount of radioactivity was applied to each sample. Representative findings of three separate experiments are shown. The origin is marked by an asterisk. Arrows 1 and 2 indicate the first dimension of electrophoresis and second dimension of the ascending chromatography, respectively.

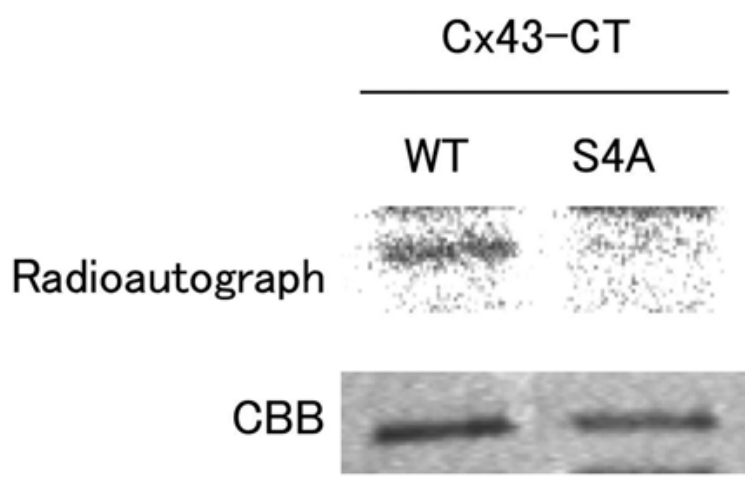

Fig. 6. In vitro phosphorylation reactions with the catalytic subunit of PKA. One unit of the catalytic subunit of PKA was incubated with either the Cx43-CT or Cx43CTS4A in which Ser365, Ser368, Ser369, and Ser373 were substituted with alanine. Reaction products were visualized as in Fig. 4.

connexin 43 mRNA in granulosa cells is significantly enhanced by pregnant mare's serum gonadotropin (PMSG) and down-regulated with the additional administration of human chorionic gonadotropin (hCG) $[9,22]$. FSH is the central hormone of the female reproductive system [23], and the crucial role played by FSH signaling in the female reproductive system has been illustrated by 
the mouse phenotype carrying a targeted mutation in the FSH- $\beta$ subunit gene $[24,25]$ and by the effects of mutations in mouse and human FSH receptor molecules [26-28]. Namely, FSH-deficient female mice were infertile due to a block in folliculogenesis prior to formation of the antral follicle [24]. In a similar fashion, the indispensable role of gap junctions in the female reproductive process has been demonstrated recently by targeted disruption of certain connexin genes [29-32]. Defects in the development of oocytes and follicles have been reported in Cx37 [32, 33] and Cx43 [34, 35] knockout mice, respectively. Notably in the absence of Cx43, granulosa cells stop growing at an early preantral stage, and in Cx43 null mice, the development of follicles arrests in the preantral stage [36]. Gap junctional intercellular communication mediated by $\mathrm{C} \times 33$ thus seems to play indispensable roles in both germ line development and postnatal folliculogenesis, and understanding how FSH regulates Cx43-mediated GJC is important.

Signaling mechanisms downstream of the FSH receptor have been studied well. The FSH receptor is a $G$ protein-coupled receptor, once bound with FSH, it activates adenylyl cyclase leading to production of cAMP. Then, cAMP activates the PKA-dependent pathways involving ERK and the transcription factor cyclic AMP response element binding protein (CREB), as well as PKAindependent pathways involving protein kinase $B$ (PKB/Akt), serum and glucocorticoid-induced kinase (SGK), and p38 through cAMP-regulated guanine nucleotide exchange factor (cAMP-GEF) [37]. We demonstrated in this study that enhanced phosphorylation of $\mathrm{Cx} 43$ induced by stimulation with FSH in rat granulosa cells depends on the PKA pathway, while the activity of ERK was dispensable. Moreover, the catalytic subunit of PKA could phosphorylate Cx43-CT, at least in vitro, further supporting this notion. However, since H89 treatment could not inhibit phosphorylation of Cx43 completely in vivo or in vitro, the possibility of involvement of other kinase(s) cannot be excluded.

Various kinds of protein kinases have been shown to be involved in phosphorylation of Cx43 [38] in addition to PKA as shown in this study. Phosphorylation of connexin has been implicated in the regulation of gap junctional communication at multiple levels, including trafficking, assembly/ disassembly, stability, and channel activity. For example, phosphorylation of Y265 by nonreceptortype tyrosine kinase Src is known to lead to an inhibition of intercellular communication [39]. Further, phosphorylation of S255/279/282 by mitogen-activated protein kinase (MAPK) also disrupts gap junctional communication [11, 13]. We previously found that FSH accelerated trafficking of $\mathrm{Cx} 43$ and accumulation of this protein in gap junctional plaques accompanying phosphorylation in rat granulosa cells [40]. We further identified Ser365, Ser368, Ser369, and Ser373 as major sites of phosphorylation, and revealed the significance of serine phosphorylation in Cx43-mediated channel activity [16]. Namely, when all four serine residues were substituted with alanine, Cx43 appeared to lose dye transfer activity. We demonstrated in this study that these four serine residues could be the target sites of PKA. Therefore, it may be reasonable to suggest that PKA positively regulates $\mathrm{C} x 43$-mediated gap junctional communication in the presence of FSH through phosphorylation of Ser365, Ser368, Ser369, and Ser373.

Finally, we showed in this study the relevance of $\mathrm{FSH} / \mathrm{PKA}$ signaling to the regulation of $\mathrm{Cx} 43$ mediated gap junctional communication in granulosa cells. What is the significance of this finding on ovarian folliculogenesis and/or oogenesis? With regard to this, Cx37 is believed to be the only connexin protein supplied from oocytes for the gap junctional channel connecting granulosa cells and oocytes [33]. Supporting this, Gittens and Kidder recently reported using reconstituted chimeric ovaries from Cx37- or Cx43-deficient mice that expression of Cx37 in oocytes, but not granulosa cells, was prerequisite for follicular development [41]. Multiple connexins including $\mathrm{C} \times 43$, however, are known to be expressed in granulosa cells $[9,10]$, and the counterpart of Cx37 functioning in the contact region of granulosa cells and oocytes is still unknown. Clarifying the exact localization of $\mathrm{Cx} 43$ and its possible formation of a heterotypic gap junction with Cx37 in this region would thus be required to extend our understanding of the mechanisms of oocyte growth and maturation in ovarian follicles. 


\section{References}

1. Goodenough DA, Goliger JA, Paul DL. Connexins, connexons, and intercellular communication. Annu Rev Biochem 1996; 65: 475-502.

2. Kumar NM, Gilula NB. The gap junction communication channel. Cell 1996; 84: 381-388.

3. Martin PEM, Evans WH. Incorporation of connexins into plasma membranes and gap junctions. Cardiovasc Res 2004; 62: 378-387.

4. Willecke K, Eiberer J, Degen J, Eckardt D, Romualsi A, Guldenagel M, Deutsch U, Sohl G. Structural and functional diversity of connexin genes in the mouse and human genome. Biol Chem 2002; 383: 725-737.

5. Eppig JJ. Oocyte-somatic cell communication in the ovarian follicles of mammals. Semin Dev Biol 1994; 5: 51-59.

6. Kidder GM, Mhawi AA. Gap junctions and ovarian folliculogenesis. Reproduction 2002; 123: 613-620.

7. Heller DT, Cahill DM, Schultz RM. Biochemical studies of mammalian oogenesis: metabolic cooperativity between granulosa cells and growing mouse oocytes. Dev Biol 1981; 84: 455-464.

8. Brower PT, Schultz RM. Intercellular communication between granulosa cells and mouse oocytes: existence and possible nutritional role during oocyte growth. Dev Biol 1982; 90: 144-153.

9. Itahana K, Morikazu Y, Takeya T. Differential expression of four connexin genes, Cx-26, Cx30.3, Cx32, and Cx43, in the porcine ovarian follicle. Endocrinology 1996; 137: 5036-5044.

10. Itahana $\mathbf{K}$, Tanaka T, Morikazu Y, Komatu S, Ishida N, Takeya T. Isolation and characterization of a novel connexin gene, $\mathrm{Cx}-60$, in porcine ovarian follicles. Endocrinology 1998; 139: 320-329.

11. Warn-Cramer BJ, Lampe PD, Kurata WE, Kanemitsu MY, Loo LW, Eckhart W, Lau AF. Characterization of the mitogen-activated protein kinase phosphorylation sites on the connexin-43 gap junction protein. J Biol Chem 1996; 271: 3779-3786.

12. Laing JG, Tadros PN, Westphale EM, Beyer EC. Degradation of connexin 43 gap junctions involves both the proteasome and the lysosome. Exp Cell Res 1997; 236: 482-492.

13. Warn-Cramer BJ, Cottrell GT, Burt JM, Lau AF. Regulation of connexin-43 gap junctional intercellular communication by mitogen-activated protein kinase. J Biol Chem 1998; 273: 9188-9196.

14. Zhou L, Kasperek EM, Nicholson BJ. Dissection of the molecular basis of pp60 $60^{\mathrm{v}-s r}$ induced gating of connexin 43 gap junciton channels. J Cell Biol 1999; 144: 1033-1045.

15. Akiyama M, Ishida N, Ogawa T, Yogo K, Takeya T. Molecular cloning and functional analysis of a novel Cx43 partner protein CIP150. Biochem Biophys Res Commun 2005; 335: 1264-1271.
16. Yogo K, Ogawa T, Akiyama M, Ishida N, Takeya T. Identification and functional analysis of novel phosphorylation sites in $\mathrm{Cx} 43$ in rat primary granulosa cells. FEBS Lett 2002; 531: 132-136.

17. Ogawa T, Yogo K, Ishida N, Takeya T. Synergistic effects of activin and FSH on hyperphosphorylation of $\mathrm{Rb}$ and $\mathrm{G} 1 / \mathrm{S}$ transition in rat primary granulosa cells. Mol Cell Endocrinol 2003; 210: 31-38.

18. Chijiwa T, Mishima A, Hagiwara M, Sano $\mathbf{M}$, Hayashi K, Inoue T, Naito K, Toshioka T, Hidaka $\mathrm{H}$. Inhibition of forskolin-induced neurite outgrowth and protein phosphorylation by a newly synthesized selective inhibitor of cyclic AMP-dependent protein kinase, N-[2-( $p$ bromocinnamylamino)-ethyl $]-5-$ isoquinolinesulfonamide (H-89), of PC12D pheochromocytoma cells. J Biol Chem 1990; 265: 5267-5272.

19. Sato M, Kato JY, Takeya T. Characterization of partly activated p60-src in chicken embryo fibroblasts. J Virol 1989; 63: 683-688.

20. Kanemitsu MY, Lau AF. 1993. Epidermal growth factor stimulates the disruption of gap junctional communication and connexin 43 phosphorylation independent of 12-O-tetradeca-noylphorbol 13acetate-sensitive protein kinase C: the possible involvement of mitogen-activated protein kinase. Mol Biol Cell 1993; 4: 837-848.

21. Das S, Maizels ET, DeManno D, St Clair E, Adam SA, Hunzicker-Dunn M. A stimulatory role of cyclic adenosine 3', 5'-monophosphate in folliclestimulating hormone-activated mitogen-activated protein kinase signaling pathway in rat ovarian granulosa cells. Endocrinology 1996; 137: 967-974.

22. Granot I, Dekel N. Phosphorylation and expression of connexin-43 ovarian gap junction protein are regulated by luteinizing hormone. J Biol Chem 1994; 269: 30502-30509.

23. Bousfield GR, Perry WM, Ward DN. Gonadotropins: chemistry and biosynthesis. In: Knobil E, Neill JD (eds.), The Physiology of Reproduction. Raven Press: New York: 1994; 17491792.

24. Kumar TR, Wang Y, Lu N, Matzuk MM. Follicle stimulating hormone is required for ovarian follicle maturation but not male fertility. Nat Genet 1997; 15: 201-204.

25. Burns KH, Yan C, Kumar TR, Matzuk MM. Analysis of ovarian gene expression in folliclestimulating hormone $\beta$ knockout mice. Endocrinology 2001; 142: 2742-2751.

26. Aittomaki K, Lucena JLD, Pakarien P, Sistonen $\mathbf{P}$, Tapanainen J, Gromoll J, Kaskikari R, Sankila EM, Lehvaslaiho H, Engel AR, Nieschlag E, Huhtaniemi I, de la Chapelle A. Mutation in the follicle-stimulating hormone receptor gene causes hereditary hypergonadotropic ovarian failure. Cell 
1995; 82: 959-968.

27. Dierich A, Sairam MR, Monaco L, Fimia GM, Gansmuller A, LeMeur M, Sassone-Corsi P. Impairing follicle-stimulating hormone (FSH) signaling in vivo: targeted disruption of the FSH receptor leads to aberrant gametogenesis and hormonal imbalance. Proc Nat Acad Sci USA 1998; 95: 13612-13617.

28. Layman LC, McDonough PG. Mutations of follicle stimulating hormone- $\beta$ and its receptor in human and mouse: genotype/phenotype. Mol Cell Endocrinol 2000; 161: 9-17.

29. Elvin JA, Matzuk MM. Mouse models of ovarian failure. Rev Repro 1998; 3: 183-195.

30. Simon AM, Goodenough DA. Diverse functions of vertebrate gap junctions. Trends Cell Biol 1998; 8: 477-482.

31. White T, Paul DL. Genetic diseases and gene knockouts reveal diverse connexin functions. Annu Rev Physiol 1999; 61: 283-310.

32. Carabatos MJ, Sellitto C, Goodenough DA, Albertini DF. Oocyte-granulosa cell heterologous gap junctions are required for the coordination of nuclear and cytoplasmic meiotic competence. Dev Biol 2000; 226: 167-179.

33. Simon AM, Goodenough DA, Li E, Paul DL. Female infertility in mice lacking connexin37. Nature 1997; 385: 525-529.

34. Ackert CL, Gittens JEI, O'Brien MJ, Eppig, JJ, Kidder GM. Intercellular communication via connexin43 gap junctions is required for ovarian folliculogenesis in the mouse. Dev Biol 2001; 233: 258-270.

35. Juneja SC, Barr KJ, Enders GC, Kidder GM. Defects in the germ line and gonads of mice lacking connexin43. Biol Reprod 1999; 60: 1263-1270.

36. Gittens J, Mhawi AA, Lidington D, Oullette Y, Kidder GM. Functional analysis of gap junctions in ovarian granulosa cells: distinct role for connexin 43 in early stages of folliculogenesis. Am J Physiol Cell Physiol 2003; 284: C880-C887.

37. Richards JS. New Signaling pathways for hormones and cyclic Adenosine 3',5'-monophosphate action in endocrine cells. Mol Endocrinol 2001; 15: 209-218.

38. Lampe PD, Lau AF. The effects of connexin phosphorylation on gap junctional communication. Int J Biochem Cell Biol 2004; 36: 1171-1186.

39. Lin R, Warn-Cramer BJ, Kurata WE, Lau AF. v-Src phosphorylation of connexin 43 on Tyr247 and Tyr265 disrupts gap junctional communication. J Cell Biol 2001; 154: 815-827.

40. Yogo K, Ogawa T, Akiyama M, Ishida N, Takeya T. Gap junctions in ovarian folliculogenesis. In: Sato E, Miyamoto H, Manabe N (eds.), Animal Frontier Sciences: Life Science Update in Animal Science. Kyoto; Hokuto Shobo; 2003: 97-102.

41. Gittens JE, Kidder GM. Differential contributions of connexin 37 and connexin 43 to oogenesis revealed in chimeric reaggregated mouse ovaries. J Cell Sci 2005; 118: 5071-5078. 